https://doi.org/10.15407/frg2020.03.196

UDK 577.21: 57.085.1:577.233.3:633

\title{
DETECTION OF DNA POLYMORPHISM OF TRANSGENIC WHEAT PLANTS WITH PROLINE METABOLISM HETEROLOGOUS GENES
}

\author{
O.V. DUBROVNA ${ }^{1}$, L.G. VELIKOZHON ${ }^{1}$, L.V. SLIVKA ${ }^{1}$, I.P. KONDRATSKAYA ${ }^{2}$, \\ V.N. RESHETNIKOV ${ }^{2}$, S. MAKAI ${ }^{3}$ \\ ${ }^{1}$ Institute of Plant Physiology and Genetics, National Academy of Sciences of \\ Ukraine \\ 31/17 Vasylkivska St., Kyiv, 03022, Ukraine \\ e-mail:dubrovny@ukr.net \\ ${ }^{2}$ Central Botanical Garden, National Academy of Sciences of Belarus \\ $2 v$ Surganov St., Minsk, 220012, Republic of Belarus \\ ${ }^{3}$ University of West-Hungary, \\ 2 Var St., Mosonmagyarovar, H-9200, Republic of Hungary
}

The polymorphism level of DNA regions flanked by inverted LTR-retrotransposon repeats has been analyzed by the IRAP-PCR method in genetically modified wheat plants obtained by Agrobacterium-mediated transformation in an in vitro culture. Some plants contain the Medicago truncatula ornithine- $\delta$-aminotransferase gene, and the other contain a double-stranded RNA suppressor of the Arabidopsis thaliana proline dehydrogenase gene. In analysis of plants with the heterologous ornithine- $\delta$-aminotransferase gene, the application of the primer to the Sukkula retrotransposon was the most effective, where in the nine tested plants four new amplicons were obtained in the spectrum of DNA amplification products. The findings suggest that it is the foreign DNA insertion capable of inducing transposition of retrotransposons Sukkula/Nikita and Wham/Sabrina, because in control plants derived from in vitro culture their activity has not been established. The analysis of transgenic plants with a double-stranded RNA suppressor of the proline dehydrogenase gene using highly efficient primers for the retrotransposons Sukkula, Sabrina, Wham, Nikita, and Wilmal no DNA polymorphism was revealed. In the course of the experiment, we did not register the disappearance of amplicons in the DNA profiles of PCR and this may be index of the rearrangements absence in the primer annealing sites and in the loci studied. The emergence of new amplicons was not observed in the spectra of DNA amplification products, what indicate the absence of activation of mobile genetic elements transposon activity in transgenic plants with a double-stranded RNA suppressor of the proline dehydrogenase gene. IRAP primer pairs were selected experimentally, but the use of this method did not reveal the disappearance or emergence of polymorphic fragments. The absence of DNA polymorphism in transgenic plants with a double-stranded RNA suppressor of the proline dehydrogenase gene may be due to the phenomenon of RNA interference that suppresses retrotransposon activity.

Key words: Triticum aestivum, Agrobacterium-mediated transformation, genes of proline metabolism, retrotransposons, IRAP-PCR.

Citation: Dubrovna O.V., Velikozhon L.G., Slivka L.V., Kondratskaya I.P., Reshetnikov V.N., Makai S. Detection of DNA polymorphism of transgenic wheat plants with proline metabolism heterologous genes. Fiziol. rast. genet., 2020, 52, No. 3, pp. 196207. https://doi.org/10.15407/frg2020.03.196

196 
The main methods for obtaining genetically modified plants are based on the transfer of T-DNA into cultured in vitro cells with subsequent regeneration of transformed shoots [1]. A significant number of mutations known under the general name of somaclonal variability may occur under these conditions [2-4]. However, beside the mutagenic effect of tissue culturing, the transformation process is accompanied by additional stress associated with mechanical wounding, cultivation on selective media, and the incorporation of a genetic construct into the recipient's genome [5]. It should be noted that the mutation process induced by Agrobacterium-mediated transformation is a side effect that accompanies the creation of genetically modified plants. It is important to study this process, because the insertion of exogenous DNA can lead to large-scale chromosomal alterations and greatly change the plants phenotype, in addition to the effect on individual genes functioning [6, 7]. Impairment in the stability of the transformed plant's genome can be a consequence of foreign DNA transfer, but this problem is not paid sufficient attention to, even though these studies are related to the fundamental issues of genome organization and functioning as a whole and to the problem of transgenic plant consumption safety.

Foreign DNA integration into the nuclear genome has been shown to evoke both epigenetic changes, including changes in the DNA methylation level, and activation of mobile genetic elements (MGEs) transcription [8]. The data obtained by Matzke et al. [9, 10] convincingly testify that an increase in the frequency of genetic rearrangements and MGE activation in the recipient's genome is observed in the presence of transgenes. The transposition phenomenon is of considerable interest, since its role in both the changes in structural genes expression and the chromosomal aberrations induction has been demonstrated [11, 12].

The data on mobile genetic elements accumulated to date have enabled the development of methods for assessment of the DNA polymorphism regions flanked by inverted repeats, in particular by the long terminal regions (LTRs) of retrotransposons [13]. The LTR-retrotransposon sequences are used to detect polymorphisms among different forms of the same species by means of PCR fingerprinting with the IRAP, REMAP, and SSAP methods [13, 14]. IRAP (Inter Retrotransposon Amplified Polymorphism) is a method for the amplification of genomic DNA flanked by neighboring retrotransposon sequences [13]. The PCR product of DNA amplification is a stable genetic IRAP marker. In this case, polymorphism is either due to a mutation in the primer annealing site or to a unique biological process of retrotransposition, that is, retrotransposon incorporation into a new genomic DNA region without loss of the initial site. Simultaneous analysis of multiple anonymous loci in different parts of the genome and identification of genome modifications, including those caused by the action of stress factors, are the advantages of using the IRAP analytical method. Therefore, polymorphism of the spectra of inter retrotransposon sequences can serve as an objective criterion for genome variability.

Scientific publications on the evaluation of transgenic plants by IRAP analysis are currently very scarce [15-20]. Their results indicate that the genetic transformation of plants can cause retrotransposon displacement and evoke transposition. We used the IRAP method to investigate MGE activity in callus lines of the Zimoyarka wheat variety transformed by the pAHC25 vector construct [18]. A primer related to the LTR sequences of 
the SIRE-1 retrotransposon was used. The emergence of new amplicons of a relatively large size (longer than $1000 \mathrm{bp}$ ) was detected in three transformed lines. The emergence of several new amplicons and the detection of these amplicons in three of the seven callus lines studied may be the index of a relatively high frequency of transposition events in the transformants' DNA. The method we used does not allow for direct detection of the retrotransposons transcriptional activity, but it can be a quick and efficient tool for studies of genome changes associated with genetic transformation and validation of MGE transcription.

The aim of our work was comparative analysis of the polymorphism level of DNA regions flanked by inverted LTR repeats of retrotransposons in transgenic wheat plants obtained by Agrobacterium-mediated transformation in an in vitro culture. Some plants contain the Medicago truncatula ornithine- $\delta$-aminotransferase gene, and the other contains a double-stranded RNA suppressor of the Arabidopsis thaliana proline dehydrogenase gene.

\section{Materials and methods}

Bread wheat Zimoyarka variety control regenerants of the $\mathrm{R}_{0}$ generation obtained from calluses without genetic transformation (ten plants) and transgenic $T_{0}$ regenerants of the Zimoyarka variety (fourteen plants) were used as the research material in each individual experiment. The $\mathrm{T}_{0}$ plants were obtained by the Agrobacterium-mediated transformation method with the AGL0 strain that contained the binary $\mathrm{pBi}-\mathrm{OAT}$ or $\mathrm{pBi} 2 \mathrm{E}$ vector constructs. This constructs, kindly provided by O.V. Kochetov, Dr. Sci. (Biol.) (Institute of Cytology and Genetics, Siberian Branch, Russian Academy of Sciences, Novosibirsk, Russia). pBi-OAT vector construct included the heterologous Medicago truncatula ornithine- $\delta$-aminotransferase gene and the selective neomycin phosphotransferase II (nptII) gene from E. coli; $\mathrm{pBi} 2 \mathrm{E}$ vector construct included the heterologous double-stranded RNA suppressor of the Arabidopsis proline dehydrogenase gene and the selective neomycin phosphotransferase II (nptII) gene from E. coli. Conditions for the implementation of Agrobacterium-mediated transformation are described in [21]. The plants transgenic status was verified by PCR. DNA extraction from leaves was performed with the DNA-sorb-C reagent kit (Central Rospotrebnadzor Institute of Epidemiology Research, Russia). DNA concentration and purity were determined spectrophotometrically. PCR was performed in the Mastercycler Personal 5332 Eppendorf amplifier. The final volume of the reaction mixture was $20 \mu \mathrm{l}$, and its composition was as follows: $10 \mathrm{mM}$ Tris- $\mathrm{HCl}, 50 \mathrm{mM} \mathrm{KCl}, 2 \mathrm{mM}$ magnesium chloride, $0.2 \mathrm{mM}$ each deoxynucleotide triphosphate (dNTP), $0.2 \mathrm{mM}$ primer, 1 activity unit Taq DNA polymerase, and 100-130 ng of the DNA studied.

The amplification program was as follows: initial denaturation at $94{ }^{\circ} \mathrm{C}$ for $4 \mathrm{~min}, 34$ cycles (denaturation at $94{ }^{\circ} \mathrm{C}$ for $30 \mathrm{~s}$, annealing at $55^{\circ} \mathrm{C}$ for $1 \mathrm{~min}$, and elongation at $72{ }^{\circ} \mathrm{C}$ for $3 \mathrm{~min}$ ), and final elongation at $72{ }^{\circ} \mathrm{C}$ for $5 \mathrm{~min}$. Efficiency of the IRAP primers for LTR sites of different retrotransposons used in the study (Table) had been demonstrated in the analysis of cereal plants [22].

Individual primers or primer combinations (two primers at the same time) were added to the reaction mix. Amplification products were sepa- 


\begin{tabular}{l|c|r}
\hline \multicolumn{2}{c}{ IRAP primers used in the study } \\
\hline \multicolumn{1}{c}{ Primer } & Retrotransposon & Nucleotide sequence \\
\hline Wis & Wis2 & 5'-TAATTTCTGCAACGTTCCCCAACA-3' \\
Wil & Wilma1 & 5'-AGCATGATGCAAAATGGACGTATCA-3' \\
Wi2 & Wilma2 & 5'-AGAGCCTTCTGCTCCTCGTTGGGT-3' \\
$\mathrm{Da}$ & Daniela & 5'-TACCCCTACTTTAGTACACCGACA-3' \\
$\mathrm{Wh}$ & Wham & 5'-GGAAAAGTAGATACGACGGAGACGT-3' \\
$\mathrm{Ni}$ & Nikita & 5'-CGCTCCAGCGGTACTGCC-3' \\
$\mathrm{Sa}$ & Sabrina & 5'-GCAAGCTTCCGTTTCCGC-3' \\
$\mathrm{Su}$ & Sukkula & 5'-GATAGGGTCGCATCTTGGGCGTGAC-3' \\
$\mathrm{St}$ & Stowaway & 5'-CTTATATTTAGGAACGGAGGGAGT-3' \\
\hline
\end{tabular}

rated in a $1.5 \%$ agarose gel, stained with ethidium bromide solution, visualized in ultraviolet light, and photographed.

The GeneRuler DNA Ladder Mix (Thermo Fisher Scientific) was used to estimate the size of the amplification products. The size of the PCR products was determined in the TotalLab v. 2.01 software (Nonlinear Dynamics). The stability of amplicon formation was verified by performing the amplification in triplicate for each sample of plant material.

\section{Results and discussion}

Validating the efficiency of the primers used and the possibility of their using for wheat genome analysis was important at the first stage of the study. To fulfill these tasks, PCR with each individual primer was performed with DNA samples of the original variety ten random plants according to the procedures described. The primers suitable for further use ( $\mathrm{Su}, \mathrm{Sa}, \mathrm{Wh}, \mathrm{Ni}$ and Wil) were identified according to the character of the DNA amplification spectra products obtained: the use of these primers allowed for reliable identification of certain numbers of amplicons in the PCR spectra, while others were inefficient.

Initially, we determined the genetic homogeneity of control plants in the loci studied. All highly efficient primers ( $\mathrm{Su}, \mathrm{Sa}, \mathrm{Wh}, \mathrm{Ni}$, and Wi1) produced identical spectra of amplification products from the DNA of different plants (Fig. 1). The data obtained demonstrate the absence of natural and/or spontaneous polymorphism of the loci studied in the source material (plants). We did not succeed in observing transposition in the source and control forms under the experimental conditions. In general, the spectrum of DNA amplification products in the nontransgenic plants depended on the primer used and consisted of 7-16 fragments of 305 to $3300 \mathrm{bp}$ in size.

Detection of polymorphism in the genome of transgenic wheat plants was the next step of the study. Primers for which the efficiency was demonstrated in the control plants were used at this step. For plants containing the ornithine- $\delta$-aminotransferase heterologous gene, the most informative was the application of the primer to the Sukkula retrotransposon (Fig. 2, $a$ ).

Thus, with the above primer, four new amplicons were obtained in the spectrum of DNA amplification products: $507 \mathrm{bp}, 623 \mathrm{bp}, 697 \mathrm{bp}$ and 


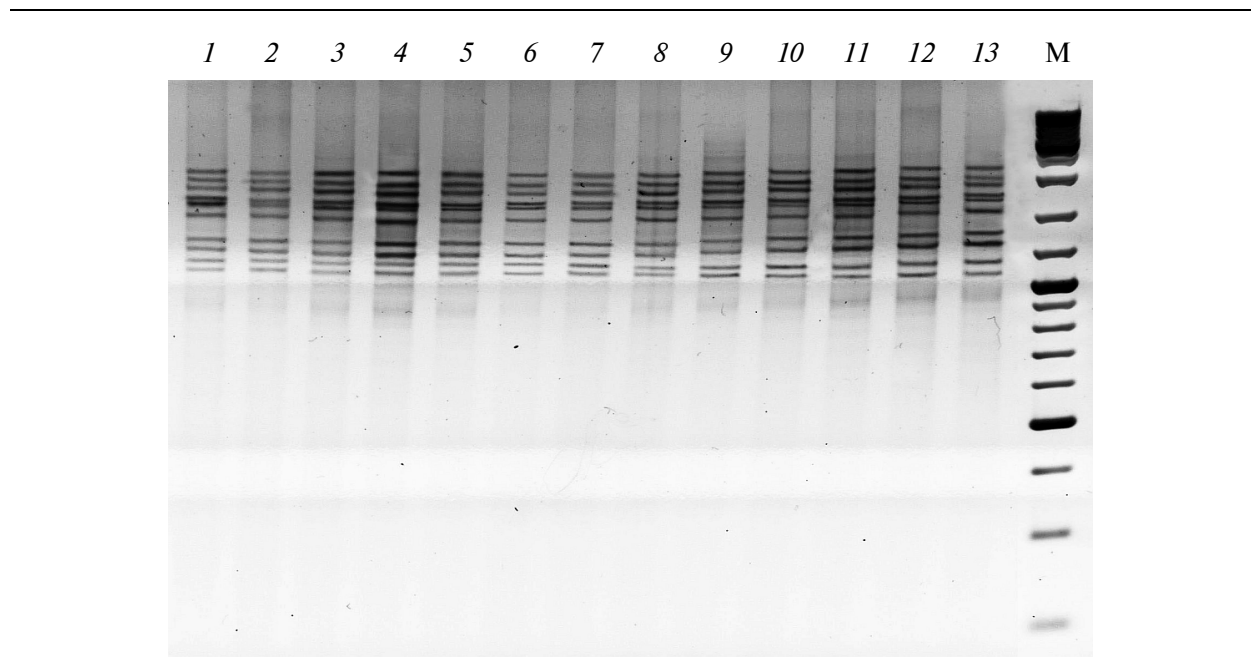

Fig. 1. Spectrum of DNA amplification products of the samples tested with the Wil primer: M - molecular weight marker (GeneRuler DNA Ladder Mix); 1-7 - plants of the initial Zimoyarka variety; $8-13-$ control regenerant plants

$920 \mathrm{bp}$ in the nine plants studied. The data obtained indicate twelve independent events of the Sukkula retrotransposon transposition in transformants. No other primers polymorphism was detected.

Nine transformants shown the emergence of new, relatively low molecular weight (less than $1000 \mathrm{bp}$ ) amplicons. The emergence of several new amplicons, as well as those found in nine of the fourteen studied plants, could indicate a relatively high frequency of transposition events in transgenic DNA. Because new DNA fragments were found in most of the investigated forms and were absent in control plants, this may indicate that the induction of Sukkula retrotransposon transposition in transformants may be due to genomic stress caused by foreign DNA incorporation or directly transformation-related stress, (micropore, coculture with Agrobacterium, cultivation on selective media).

Use of different IRAP primers combinations provide for an increase in the number of loci studied [13]. Therefore, we tested a procedure that involved the combined use of IRAP primers for different retrotransposons in the same reaction in order to expand the range of amplicons in the PCR products of the samples studied. The efficiency of this approach was confirmed by IRAP analysis of regenerant triticale plants obtained by cell selection on resistance to water deficit, where the use of IRAP primer pairs revealed MGE transposition [23]. IRAP primer pairs that enabled the detection of polymorphic amplicons in PCR product spectra were identified experimentally in our study. The most informative were the following combinations: $\mathrm{Su} / \mathrm{Ni}$ and $\mathrm{Wh} / \mathrm{Sa}$. In the first case, one amplicon was detected (Fig. 2, b) and in the second - three new polymorphic amplicons (Fig. 2, c).

According to Bayram [24], the cause of such phenomena is the transposition of retrotransposons. Accordingly, we found an amplicon size of $594 \mathrm{bp}$ using $\mathrm{Su} / \mathrm{Ni}$ primers and amplicons $627 \mathrm{bp}, 863 \mathrm{bp}$ and $1143 \mathrm{bp}$ using $\mathrm{Wh} / \mathrm{Sa}$ primers, that indicate activation and transposition of Sukkula/Nikita and Wham/Sabrina in the genome of genetically modified wheat plants obtained by Agrobacterium-mediated transformation in vitro. 

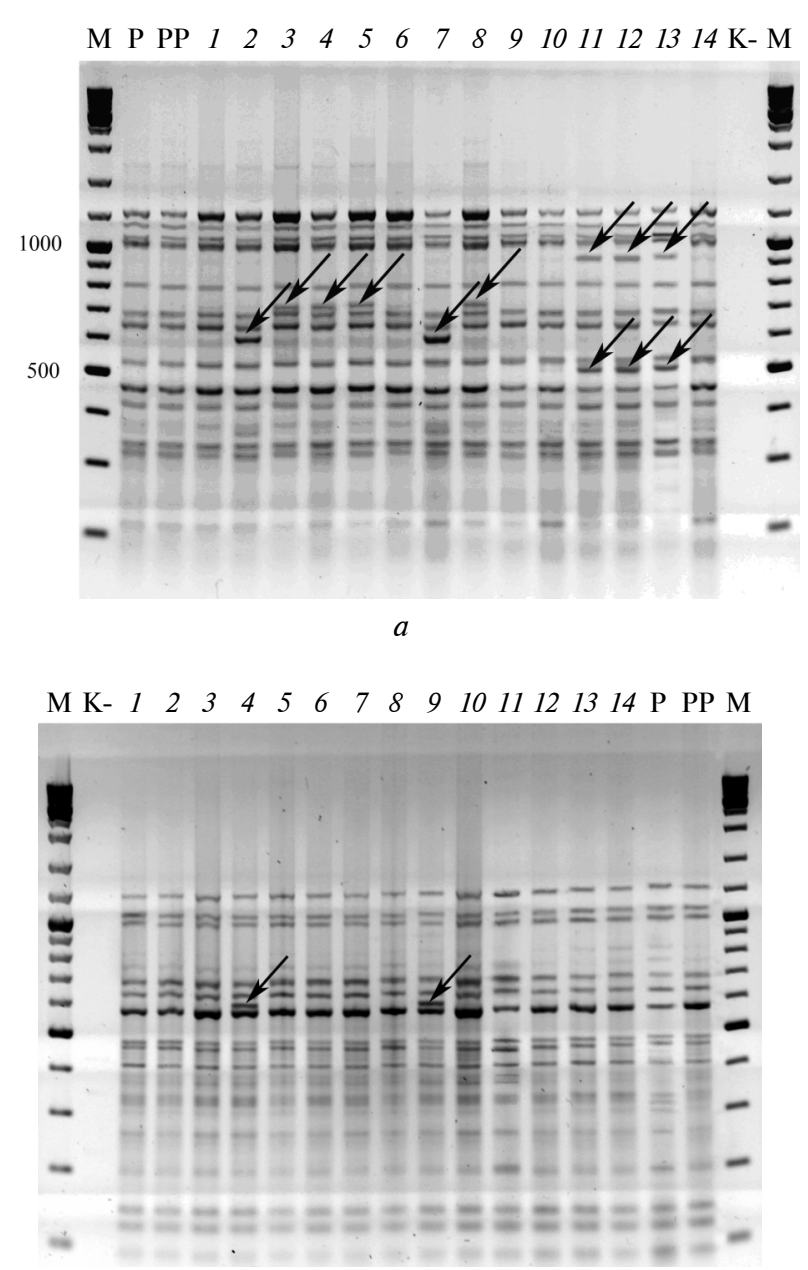

$b$

$\begin{array}{llllllllllllllllll}\text { M } & 1 & 2 & 3 & 4 & 5 & 6 & 7 & 8 & 9 & 10 & 11 & 12 & 13 & 14 & \text { P PP K- M }\end{array}$

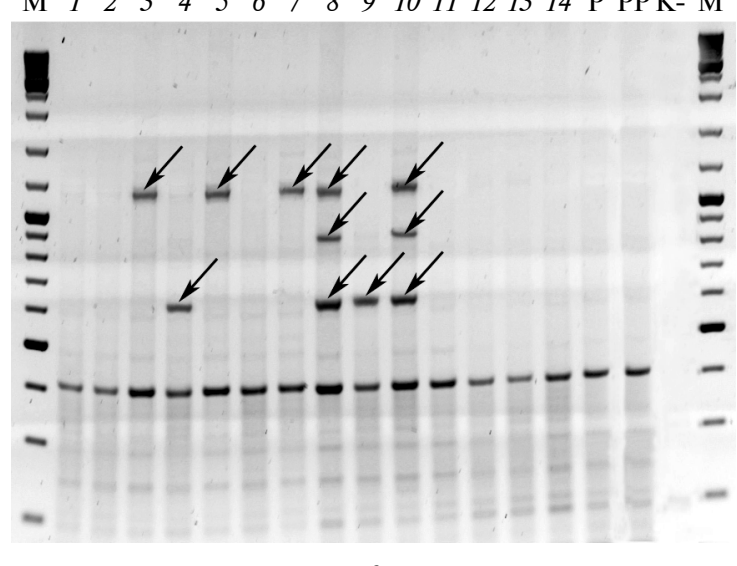

Fig. 2. Spectrum of DNA amplification products of the samples tested with the $\mathrm{Su}(a)$, and their combinations of $\mathrm{Su} / \mathrm{Ni}(b)$ and $\mathrm{Wh} / \mathrm{Sa}(c)$ :

M - GeneRuler DNA Ladder Mix molecular weight marker; the size of the fragments in bp is shown; $\mathrm{P}-$ plant of the original variety; $\mathrm{PP}$ - regenerant plant in which transformation did not occur; $1-14-$ genetically modified plants; K- - negative control (TE-buffer without DNA) 


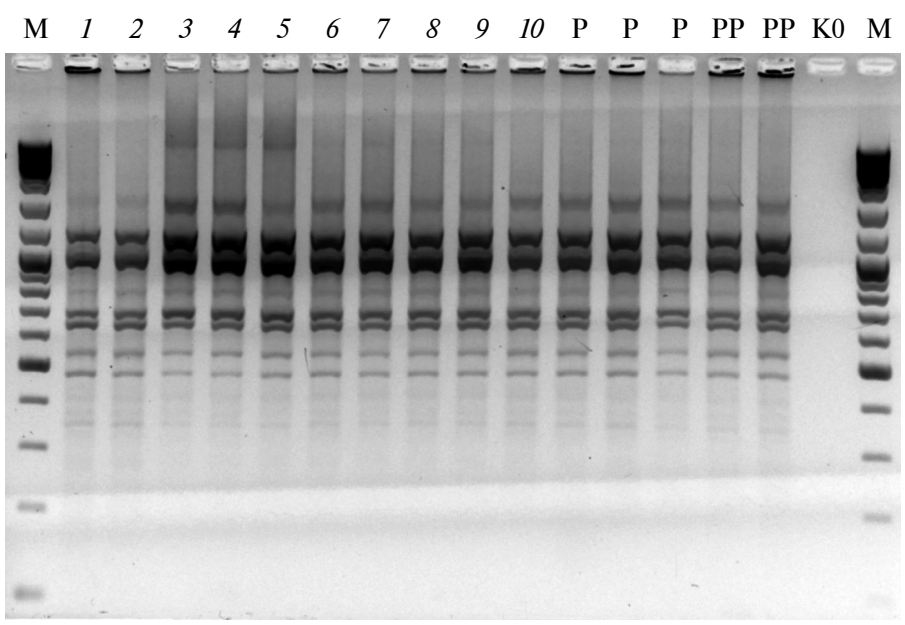

Fig. 3. Spectrum of DNA amplification products of the samples tested with the Su primers: M - GeneRuler DNA Ladder Mix molecular weight marker; P - plant of the original variety; PP regenerant plant in which transformation did not occur; $1-10-$ genetically modified plants; K0 - negative control (TE-buffer without DNA)

Under the experiment, we did not detect amplicon disappearance in PCR DNA profiles, which may indicate that there were no alterations at the primer binding sites and at the investigated loci flanked by LTR retrotransposons. Our data suggest that the insertion of foreign DNA is capable of inducing the transposition of Sukkula, Sukkula/Nikita, and Wham/Sabrina retrotransposons, because the activity of these retrotransposons was not observed in control plants derived from in vitro culture. However, the transposition of MGE may indicate a certain instability of transgenic plants genome, because in cytological study we found that transgenic forms are characterized by greater cytogenetic instability compared with non-transgenic plants [25].

Detection of polymorphism in the genome of transgenic wheat plants that carried the double stranded RNA suppressor of the proline dehydrogenase gene was the next step of the study. Primers for which the efficiency was demonstrated in the control plants were used at this step. DNA polymorphism was not detected in the transgenic plants with any highly efficient primer (Fig. 3). We did not register changes in the DNA profiles of PCR under the experimental conditions, and this may indicate the absence of rearrangements in primer annealing sites and the loci flanked by retrotransposon LTRs.

The use of IRAP primer pairs did not reveal the disappearance or emergence of new polymorphic fragments (Fig. 4). It should be noted that the transposition activity of the Tos 17 retrotransposon in genetically modified rice plants [19] and Tag1 retrotransposon in Arabidopsis [26] was reported. The authors also mentioned the lack of such activity in control plants. IRAP analysis of transgenic tobacco plants obtained by Agrobacterium-mediated transformation with a genetic construct that contained the dehalogenase (dehE) gene revealed new fragments, which indicate of the activation and associated transposition of the Tto 1 retrotransposon [16]; the level of polymorphism between transgenic and control plants amounted to $20 \%$. Similar results were obtained in transgenic rice plants [20] in which IRAP analysis revealed activation and transposition of the Houba retrotransposon with the DNA polymorphism level of $56 \%$. 


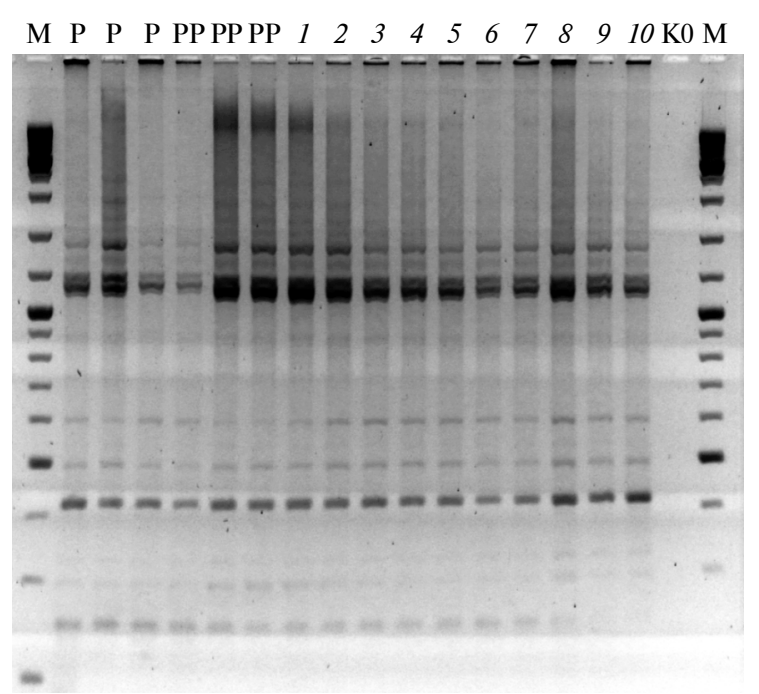

Fig. 4. Spectrum of DNA amplification products of the samples tested with the $\mathrm{Su} / \mathrm{Ni}$ primers: M - GeneRuler DNA Ladder Mix molecular weight marker; P - plant of the original variety; PP regenerant plant in which transformation did not occur; $1-10-$ genetically modified plants; $\mathrm{K} 0-$ negative control (TE-buffer without DNA)

Our studies of transgenic wheat plants with the ornithine- $\delta$-aminotransferase gene introduced by Agrobacterium-mediated transformation in an in vitro culture also demonstrated the activation and transposition of mobile genetic elements in transgenic plants. Experimental data for wheat suggest that the insertion of foreign DNA per se is capable of inducing the transposition of Sukkula, Sukkula/Nikita, and Wham/Sabrina retrotransposons, since the activity of these retrotransposons has not been detected in control plants produced in an in vitro culture. Thus, our results and the data of other researchers convincingly demonstrate that genetic transformation, including Agrobacterium-mediated transformation, can lead to the movement of retrotransposons, and the detection of the transposition effect that may be due to genomic stress caused by the introduction of foreign DNA or stress directly related to the transformation process.

However, DNA polymorphism was not detected in the analysis of transgenic plants with a double stranded RNA suppressor of the proline dehydrogenase gene, when the primers used for the analysis of transgenic Zimoyarka wheat plants carrying the ornithine- $\delta$-aminotransferase target gene were used. It is known that mechanisms for host genome protection from foreign transposition on the transcriptional (silencing by DNA methylation) and posttranscriptional (silencing through RNA interference) levels have emerged in the coevolution process $[27,28]$. Therefore, the activity of retrotransposons is absent or insignificant under normal conditions [29, 30]. Short RNAs that corresponded to retrotransposon sequences were found in plants [30], what is in agreement with the assumption on the existence of a mobile element repression mechanism associated with the formation of double stranded RNA. The repression is strengthened as the transgene copy number in the genome increases, and an increase of repression throughout several generations is observed. In this regard, the absence of DNA polymorphism in transgenic wheat plants with a double-stranded RNA suppressor of the proline dehydrogenase gene may be related to the phenomenon of RNA interference, which accounts for the inhibition of retrotransposon activity. 
Studies performed in recent years showed that short RNAs are involved in regulating the expression of numerous genes in the organism as well as in the repression of mobile elements [31, 32]. The molecular mechanism of RNA interference involves the stages described below. Long double-stranded RNA molecules are cut into smaller fragments of approximately 20-25 nucleotides (siRNA, short interfering RNA) by nucleases of the Dicer family in the cell. The siRNAs can then be incorporated into RNPs of the RISC complex (RNA induced silencing complex), which ensures the interaction of one of the short RNA strands with complementary RNA molecules present in the cytoplasm of the cell, and with mRNA in particular [43]. The RISC complex mediates the cleavage of target mRNA molecules in regions that are fully complementary to short RNAs, and, thus, mRNA is degraded. Short RNAs can suppress transcription of the homologous gene in the nucleus along with posttranscriptional repression of mRNA in the cytoplasm. An RNP complex that contains siRNA causes a local change in the chromatin structure, and the associated phenomenon is referred to as RITS (RNA-induced initiation of transcriptional silencing) [34]. Short RNAs in plants cause repression of the chromatin of complementary genes, both due to histone methylation and due to cytosine methylation in the DNA [35]. The presence of double-stranded RNAs homologous to mobile elements enables the RNA interference cell apparatus to repress the expression of these elements, which is often harmful, as it leads to transposition and, as a consequence, to mutations and chromosomal rearrangements [36]. However, it remains unclear whether the RNA interference apparatus is involved in the repression of retrotransposon chromatin or the expression is inhibited at the posttranscriptional level only due to transcript degradation. The double-stranded RNA required for the activation of the RNA interference mechanism can be derived from an external source or formed due to the transcription of a transgene, which contains an inverted repeat. In addition, double-stranded RNA is often formed upon the integration of transgenes into the host genome if aberrant transcription under a promoter located near the transgene integration site occurs [37]. The ability of double-stranded RNA to evoke the degradation of noncomplementary sequences was also reported. This phenomenon was named transitive RNA interference [38, 39].

Thus, the DNA polymorphism of transgenic wheat plants with heterologous genes of proline metabolism, obtained by Agrobacterium-mediated transformation in an in vitro culture, has been analyzed by the IRAP-PCR method. In the analysis of plants with the heterologous ornithine- $\delta$-aminotransferase gene, the application of the primer to the Sukkula retrotransposon was the most effective, where four new amplicons in the spectrum of DNA amplification products were obtained in the nine tested plants. The findings suggest that it is the insertion of foreign DNA capable of inducing transposition of retrotransposons Sukkula/Nikita and Wham/Sabrina, because in control plants derived from in vitro culture their activity has not been established.

The analysis of transgenic plants with a double-stranded RNA suppressor of the proline dehydrogenase gene using highly efficient primers for the retrotransposons of Sukkula, Sabrina, Wham, Nikita, and Wilmal revealed no DNA polymorphism. In the course of the experiment, we did not register the disappearance of amplicons in the DNA profiles of PCR 
and this may indicate the absence of rearrangements in the primer annealing sites and in the loci studied. The emergence of new amplicons was not observed in the spectra of DNA amplification products, what indicate the absence of activation of mobile genetic elements transposon activity in transgenic plants with a double-stranded RNA suppressor of the proline dehydrogenase gene. IRAP primer pairs were selected experimentally, but the use of this method did not reveal the disappearance or emergence of polymorphic fragments. The absence of DNA polymorphism in transgenic plants with a double-stranded RNA suppressor of the proline dehydrogenase gene may be due to the phenomenon of RNA interference that suppresses retrotransposon activity.

This study was funded by the budget program of support for the development of priority scientific research areas (KPKVK 6541230).

\section{REFERENCES}

1. Jones, H., Doherty, A. \& Wu, H. (2005). Review of methodologies and a protocol for the Agrobacterium mediated transformation of wheat. Plant Methods, 1, pp. 1-5. https://doi.org/10.1186/1746-4811-1-5

2. Choi, H.W., Lemaux, P.G. \& Cho, M.-J. (2000). Increased chromosomal variation in transgenic versus nontransgenic barley (Hordeum vulgare L.) plants. Crop Sci., 40, pp. 524-533.

3. Choi, H.W., Lemaux, P.G. \& Cho, M.-J. (2001). High frequency of cytogenetic aberration in transgenic oat (Avena sativa L.) plants. Plant Sci., 160, pp. 763-772. https:// doi.org/10.1016/S0168-9452(01)00369-7

4. Labra, M., Savini, C., Bracale, M., Pelucchi, N., Colombo, L., Bardini, M. \& Sala, F. Genomic changes in transgenic rice (Oryza sativa L.) plants produced by infecting calli with Agrobacterium tumefaciens. Plant Cell Rep., 20, pp. 325-330.

5. Enikeev, A.G., Kopytina, T.V., Semenova, L.A., Natyaganova, A.V., Gamanetz, L.V. \& Volkova, O.D. (2008). Agrobacterium transformation as complex biotical stressing factor. J. Stress Physiol. Biochem., 4, No. 1, pp. 11-19.

6. Flugge, U.I. \& Klosgen, R.B. (2004). Characterization of a T-DNA insertion mutant for the protein import receptor at Toc33 from chloroplasts. Mol. Genet. Genom., 272, No. 4, pp. 379-396.

7. Gaspar, Y., Nam, J., Schultz, C., Lee, L., Gilson, P., Gelvin, S. \& Bacic, A. (2004). Characterization of the Arabidopsis lysine-rich arabinogalactan-protein AtAGP17 mutant (rat1) that results in a decreased efficiency of Agrobacterium transformation. Plant Physiol., 135, No. 4, pp. 2162-2171. https://doi.org/10.1104/pp.104.045542

8. Muller, K., Heller, H. \& Doerfier, W. (2001). Foreign DNA integration. Genome-wide perturbations of methylation and transcription in the recipient genomes. J. Biol. Chem., 276, pp. 14271-14278. https://doi.org/10.1074/jbc.M009380200

9. Matzke, A.J.M. \& Matzke, M.A. (1998). Position effects and epigenetic silencing of plant transgenes. Curr. Opin. Plant Biol., 1, pp. 142-148. https://doi.org/ 10.1016/S1369-5266(98)80016-2

10. Matzke, M.A., Mette, M.F. \& Matzke, A.J.M. (2000). Transgene silencing by the host genome defense: implications for the evolution of epigenetic control mechanisms in plants and vertebrates. Plant Mol. Biol., 43, pp. 401-415.

11. Kidwell, M.G. \& Lisch, D.R. (2000). Transposable elements and host genome evolution, Trends Ecol. Evol., 15, pp. 95-99. https://doi.org/10.1016/S0169-5347

12. Todorovska, E. (2007). Retrotransposons and their role in plant-genome evolution, Biotechnol. Equip., 21, pp. 294-305. https://doi.org/10.1080/13102818.2007.10817464

13. Kalendar, R. \& Schulman, A. (2006). IRAP and REMAP for retrotransposon-based genotyping and fingerprinting. Nat. Protoc., 1, No. 5, pp. 2478-2484. https:// doi.org/10.1038/nprot.2006.377

14. Leigh, F., Kalendar, R., Lea, V., Lee, D., Donini, P. \& Schulman, A. (2003). Comparison of the utility of barley retrotransposon families for genetic analysis by molecular marker techniques. Mol. Gen. Genom., 269, pp. 464-474. https://doi.org/ $10.1007 / \mathrm{s} 00438-003-0850-2$ 
15. Schnell, J., Steele, M., Bean, J., Neuspiel, M., Girard, C., Dormann, N., Pearson, C., Savoie, A., Bourbonniere, L. \& Macdonald, P. (2015). A comparative analysis of insertional effects in genetically engineered plants: considerations for pre-market assessments. Transgen. Res., 24, No. 1, pp. 1-17. https://doi.org/10.1007/s11248-014-9843-7

16. Kaya, Y., Yilmaz, S., Gozukirmizi, N. \& Huyop, F. (2013). Evaluation of transgenic Nicotiana tabacum with dehE gene using transposon based IRAP markers. Am. J. Plant Sci., 4, No. 8A, pp. 41-44. https://doi.org/10.4236/ajps.2013.48A005

17. Rao, J., Yang, L., Guo, J., Quan, S., Chen, G., Zhao, X., Zhang, D. \& Shi, J. (2016). Development of event-specific qualitative and quantitative PCR detection methods for the transgenic maize BVLA430101. Eur. Food Res.Technol., 242, no. 8, pp. 1277-1284.

18. Bavol, A.V., Dubrovna, O.V. \& Morgun, B.V. (2013). Genetic transformation and analysis of wheat transgenic cell lines by IRAP-PCR. Biotechnol. Acta, 6, No. 6, pp. 113119 [in Ukrainian].

19. Wu, R., Guo, W., Wang, X., Wang, X., Zhuang, T., Clarke, J. \& Liu, B. (2009). Unintended consequence of plant transformation: biolistic transformation caused transpositional activation of an endogenous retrotransposon Tos17 in rice ssp. japonica cv. Matsumae. Plant Cell Rep., 28, No. 7, pp. 1043-1051. https//doi.org/10.1007/s00299009-0704-4

20. Yuzbasioglu, G., Marakli, S. \& Gozukirmizi, N. (2017). Screening of Oryza sativa L. for hpt gene and evaluation of hpt positive samples using Houba retransposonbased IRAP markers. Turk. J. Agric. Res., 4, No. 1, pp. 59-64. https://doi.org/ 10.19159/tutad.300702

21. Bavol, A.V., Dubrovna, O.V., Goncharuk, O.M. \& Voronova, S.S. (2014). Agrobacterium-mediated transformation of wheat using calli culture, Fakt. Eksp. Evol. Organism., 15, pp. 16-19 [in Ukrainian].

22. Trebichalsky, A., Kalendar, R., Schulman, A., Stratula, O., Galova, Z., Balazova, Z. \& Chnapek, M. (2013). Detection of genetic relationships among spring and winter triticale (Triticosecale Witt.) and rye cultivars (Secale cereale L.) by using retrotransposonbased markers. Czech J. Genet. Plant Breed., 49, pp. 171-174.

23. Bavol, A.V., Velikozhon, L.G., Pykalo, S.V. \& Dubrovna, O.V. (2016). IRAP-analysis of triticale plants regenerants, resistant to water deficit. Fakt. Eksp. Evol. Organism., 19, pp. 73-78 [in Ukrainian].

24. Bayram, E., Yilmaz, S. \& Hamat-Mecbur H. (2012). Nikita retrotransposon movements in callus cultures of barley (Hordeum vulgare L.). Plant OMICS: Journal of Plant Molecular Biology and Omics., 5, No. 3, pp. 211-217.

25. Bavol, A.V., Lyalko, I.I., Voronova, S.S., Goncharuk, O.M. \& Dubrovna, O.V. (2015). The course of meiosis in genetically modified wheat plants obtained by Agrobacterium - mediated transformation. Fiziol. rast. genet., 47, No. 6, pp. 536-544 [in Ukrainian].

26. Bhattm, A.M., Lister, C., Crawford, N. \& Dean, C. (1998). The transposition frequency of Tag1 elements is increased in transgenic Arabidopsis lines. Plant Cell, No. 10, pp. 427-434.

27. Casacuberta, J.M. \& Santiago, N. (2003). Plant LTR-retrotransposons and MITEs: control of transposition and impact on the evolution of plant genes and genomes. Gene, 311, pp. 1-11. https://doi.org/10.1016/S0378-1119(03)00557-2

28. Lister, R., O’Malley R., Tonti-Filippini, J., Gregory, B., Berry, C., Miller A. \& Ecker, J. (2008). Highly integrated singlebase resolution maps of the epigenome in Arabidopsis. Cell, 133, pp. 523-536. https://doi.org/10.1016/j.cell.2008.03.029

29. Choulet, F., Wicker, T., Rustenholz, C., Paux, E., Salse, J., Leroy, P., Schlub, S., Le Paslier, M., Magdelenat, G., Gonthier, C., Couloux, A., Budak, H., Breen, J., Pumphrey, M., Liu, S., Kong, X., Jia, J., Gut, M., Brunel, D., Anderson, J., Gill, B., Appels, R., Keller, B. \& Feuillet, C. (2010). Megabase level sequencing reveals contrasted organization and evolution patterns of the wheat gene and transposable element spaces. Plant Cell, 22, No. 6, pp. 1686-1701. https://doi.org/10.1105/tpc.110.074187

30. Vicient, C.M. (2010). Transcriptional activity of transposable elements in maize, BMC. Genomics, 11, No. 601, pp. 1-10. https://doi.org/10.1186/1471-2164-11-601

31. Martienssen, R.A. \& Colot, V. (2001). DNA methylation and epigenetic inheritance in plants and filamentous fungi. Science, 293, pp. 1070-1074. https://doi.org/10.1126/science.293.5532.1070

32. Mello, C.C. \& Conte, D., Jr. (2004). Revealing the world of RNA interference. Nature, 431, pp. 338-342. https://doi.org/10.1038/nature02872 
33. Meister, G. \& Tuschl, T. (2004). Mechanisms of gene silencing by double-stranded RNA. Nature, 431, pp. 343-349.

34. Verdel, A., Jia, S., Gerber, S., Sugiyama, T., Gygi, S., Grewal, S.I. \& Moazed, D., (2004). RNAi-mediated targeting of heterochromatin by the RITS complex. Science, 303, No. 5658, pp. 672-676. https://doi.org/10.1126/science. 1093686

35. Mette, M.F., Aufsatz, W., van der Winden, J., Matzke, M.A. \& Matzke, A.J., (2000). Transcriptional silencing and promoter methylation triggered by double stranded RNA. EMBO J., pp. 5194-5201. https://doi.org/10.1093/emboj/19.19.5194

36. Gvozdev, V.A. (2003). Mobile genes and RNA interference. Genetics, 39, pp. 151-156. [in Russian].

37. Makarova, Yu.A. \& Cramers, D.A. (2007). Noncoding RNA. Biochemistry, 72, No. 11, pp. 1427-1448 [in Russian].

38. Alder, M.N., Dames, S., Gaudet, J. \& Mango, S.E. (2003). Gene silencing in Caenorhabditis elegans by transitive RNA interference. RNA, 9, pp. 25-32.

39. Sijen, T., Fleenor, J., Simmer, F., Thijssen, K.L., Parrish, S., Timmons, L., Plasterk, R.H. \& Fire, A. (2001). On the role of RNA amplification in dsRNA-triggered gene silencing. Cell, 107, pp. 465-476.

Received 16.03.2020

\title{
ВИЗНАЧЕННЯ ПОЛІМОРФІЗМУ ДНК ТРАНСГЕННИХ РОСЛИН ПШЕНИЦІ 3 ГЕТЕРОЛОГіЧНИМИ ГЕНАМИ МЕТАБОЛІЗМУ ПРОЛІНУ
}

\author{
О.В. Дубровна ${ }^{1}$, Л.Г. Великожон ${ }^{1}$, Л.В. Сливка ${ }^{1}$ І.П. Кондращька ${ }^{2}$, В.М. Рєшетніков ${ }^{2}$, \\ III. Макаї
}

${ }_{1}^{1}$ Інститут фізіології рослин і генетики Національної академії наук України 03022 Київ, вул. Васильківська, 31/17, Україна

${ }^{2}$ Центральний ботанічний сад Національної академії наук Білорусі

220012 Мінськ, вул. Сурганова, 2в, Республіка Білорусь

3Університет Західної Угорщини

Н-9200, Мошонмадьяровар, вул. Вар, 2, Угорська Республіка

Методом IRAP-ПЛР проаналізовано рівень поліморфізму ділянок ДНК, фланкованих інвертованими LTR повторами ретротранспозонів у генетично модифікованих рослин пшениці, отриманих шляхом Agrobacterium-опосередкованої трансформації в культурі in vitro, частина 3 яких містить ген орнітин- $\delta$-амінотрансферази Medicago truncatula, a інша - дволанцюговий РНК-супресор гена проліндегідрогенази Arabidopsis thaliana. За аналізу рослин з гетерологічним геном орнітин- $\delta$-амінотрансферази найрезультативнішим було застосування праймера до ретротранспозону Sukkula, де в спектрі продуктів ампліфікації ДНК отримали чотири нових амплікона у дев'яти рослин. Дані свідчать, що саме інсерція чужорідної ДНК здатна індукувати транспозицію ретротранспозонів Sukkula/Nikita та Wham/Sabrina, оскільки у контрольних рослин, отриманих в культурі in vitro, ï активність не встановлена. За аналізу трансгенних рослин $з$ дволанцюговим РНК-супресором гена проліндегідрогенази при використанні високоефективних праймерів до ретротранспозонів Sukkula, Sabrina, Wham, Nikita та Wilma1 у трансгенних рослин поліморфізму ДНК не було. За умов проведеного експерименту не зареєстровано зникнення ампліконів у ДНК профілях ПЛР, що може свідчити про відсутність перебудов у сайтах зв'язування з праймером та досліджуваних локусах. У спектрах продуктів ампліфікації ДНК не відмічено появи нових ампліконів, що свідчить про відсутність активації транспозиційної активності МГЕ у досліджених трансгенних рослин з дволанцюговим РНК-супресором гена проліндегідрогенази. Експериментально були підібрані пари IRAP-праймерів, проте і за використання цього способу не було зникнення або появи нових поліморфних фрагментів. Відсутність поліморфізму ДНК у трансгенних рослин з дволанцюговим РНК-супресором гена проліндегідрогенази може бути пов'язана з РНК-інтерференцією, яка пригнічує активність ретротранспозонів.

Ключові слова: Triticum aestivum, Agrobacterium-опосередкована трансформація, гени метаболізму проліну, ретротранспозони, IRAP-PCR. 